した Program を容易に作成し，命までの煩雑な処理を 迅速に行なえた。さらに，臨床面においても，既存のプ ログラムを使用するだけではなく，各施設における，臨 床の場に合うた Program をユーザが作成する事が容易 となり，今後の発展が期待できる.

\section{ECT による甲状腺重量算出の試み}

天理よろづ相談所病院放射線科

○宮本忠彦・佐藤絃市 駒木拓行 · 中村 勝

甲状腺重量は，バセドウ病のアイソトープ治療におい て，投与量を算定するうえで最も重要な因子の一つであ る. 今回，われわれは Maxi Camera $400 \mathrm{~T} / 61$ を用いて， ECTにより甲状腺重量を算出する方法を試み, Allen 式 またはその変法を利用した，從来の平面面積法と比較検 討した。

甲状腺は臟器む小さく, ECT の回転半径も大きくな るためECTには適さないと言われているか，今回行な った方法では，ECT 法により得られた甲状腺重量は；平 面面積法之一般に良好な相関関係を示し，之くに，甲状 腺の変形のあるもの, 術後の片側欠損例や結節性甲状腺 の甲状腺重量の測定に有用之考えられた。

\section{9. 負荷心筋シンチグラムにおける再分布時間の検討}

国立循環器病センタ一放射線䛦療部

岡尚詞・田中啓子・林 真
山田幸典 - 横山博典

負荷心筋シンチグラムにおいて，その再分布像より心 筯虚血の状態をみることは狭心症の判定に重要である：

今回私達は再分布像を 2 時間毎に6〜8 時間まで追跡 し，心笳虚血部位のカウントに ROI 法や Circumferential profile 法による解析を加え ${ }^{201} \mathrm{~T} 1$ の心筇 Washout 曲線を作った。とれより至啇再分布撮像時間を求めた。

ROI 法では検討を加えた17例中 2 時間後に 8 例, 4 時 間後にはさらに8例の16例か明らかな再分布を示した。 また，Grorisによる Background Subtractionを行なっ た像に ROI 法を用いた場合も 2 時間で 9 例，4 時間で 3 例の合わせて 12 例の再分布を検出できた. Circumferential profile 法の定量解析への適応には今後の検討か 必要亡思われる。

30. 心プール検査法の精度の検討について（特に拡張期） 滋賀医科大学附属病院

○池本嘉範・増田一孝・浜津淌就 本多達哉・西村恵理子

左室機能を評価する検査法に gate 法があるが，この gate 法において，収縮期加ら急速拡張期の評価には，比
較的安定性が見られるが，緩速拡張期の評価にはデータ 収集の点から問題が残る。そこでわれわれは，自作 $\mathrm{R}$ 波 シュるレータを用い，データ取集時にトリガーとされる R波を遅延させデータ収集を行なった。そしてデータ処 時後・緩速拡張期を含奴容量曲線を得，当日発表した ように atrial contractionを中心としたIndexを求め た。とのようにして得られたIndex が，心機能評価の特 に心筋の柔軟性を表わし得ると考える。今後症例数を増 やすと共にデータ収集および処理について検討して行き たい.

\section{座長集約}

中村 幸夫 (大阪大学)

演題27席 (阪大 赫) らは，シンチカメラの固有均 一性について, RI-DATA 処理装置において, 独自に開 発したプログラムを用いて迅速に画像処理を行ない， JESRA 原案にある収集条件のうち点線源強度および計 数について検討がなされていた. RI-DATA 処理装置は 広く普及しているが，今回の報告の如く Basic 言語を基 調としたユーザーズプログラミングシステムが設けられ ているととは，今後 RI 画像処理技術の発展に大きく期 待できるととが示晙された。

演題28席（天理よろず相談所病院：窝本）引は，ECT を用いて甲状腺重量算出を行なったとてろ，従来よりの Allenの式より求めたシンチホト法とより相関を示し, 特に甲状腺の変形のあるもの, 術後の片側残存例に本法 が有用であったとの報告があったＥCT 法には吸収補 正の問題や一部に強い up take があるものは artifact $と$ して断層像に影響を与えるといわれているてとから，今 後一層本研究での測定精度の向上に期待したい.

演題29席（国立循環器病センタ一岡）らは，負荷心 筋シンチグラム亿打ける再分布時間の検討を静注後 8 時 間まで行ない，ROI 法や Circumfencial Profile 法を用 ひて解析，検討を行なったととろ，4時間後のイメーシ 为必要であるとの報告であった。再分布画像を得るとと によって狭心症の判別に有用であるが，撮像体位の再現 性の問題や解析時の統計的変動の問題が残されている.

演題30席（滋賀医大 池本）らは，平衡時法を用いた 左心機能診断（特に左心拡張早期診断）を目的として， R波トリガに独自に開発したタイムデレイ回路を用いて， R波入力にシュミレーションして収集し, DATA解析 を行なう方法が述べられた．従来R波トリガを指標とし た左心容積曲線からの解析で，特に不整脈の多い場合， 収縮末期加ら拡張早期の時相において誤差が多いとされ ているが，それを補う方法としての工夫がうかがえた。 